Original Research Paper

\title{
Evaluation of Inbred Lines and Hybrid Maize (Zea mays L.) for Tolerance to Striga hermonthica (Del.) Benth in the Guinea Savanna Agro-Ecological Zone of Ghana
}

\author{
${ }^{1}$ Bawa, A., ${ }^{2}$ M.S. Abdulai and ${ }^{1}$ I.K. Addai \\ ${ }^{1}$ University for Development Studies, Tamale, Ghana \\ ${ }^{2}$ Savanna Agricultural Research Institute (SARI), Nyankpala, Ghana
}

\author{
Article history \\ Received: 24-02-2015 \\ Revised: 4-03-2015 \\ Accepted: 10-7-2015 \\ Corresponding Author: \\ A. Bawa \\ University for Development \\ Studies, Tamale, Ghana \\ Tel: 0262980190/0243483821 \\ Email: abawai1@yahoo.com
}

\begin{abstract}
The study was conducted at the experimental field of the Savanna Agricultural Research Institute (SARI) to screen maize inbred and hybrid lines for Striga tolerance. Maize seeds of hybrid and inbred lines were collected from the West and Central African Maize Collaborative Network (WECAMAN), Boake, La Cote d'Ivoire, for the experiment. The experimental design used was the Randomized Complete Block Design (RCBD) with fourteen treatments replicated four times for the hybrids. For the inbred lines, there were twelve treatments replicated three times. The results of the hybrid experiment indicated that varieties including 9914-14 STR, 8425-8 STR, 9925-49 STR, 9916-11 STR, 9925-3 STR, CLH105 STR and CLH109 STR were comparatively better off than the others in terms of field weight and tolerance to Striga. For the inbred lines, the results indicated that GH110-5, 991228-1 and 991233-1 performed better than the rest of the varieties in terms of yield components such as plant height, days to $50 \%$ pollen shed, days to $50 \%$ silking and Striga plant rating. On Striga infested Agricultural lands, farmers can therefore use cultivars or varieties like, 9914-14 STR, 8425-8 STR, 9925-49 STR, 991611 STR, 9925-3 STR, CLH105 STR and CLH109 STR or their crosses in order to improve yield and hence maximize profit.
\end{abstract}

Keywords: Maize, Striga Tolerance, Guinea Savanna, Ghana

\section{Introduction}

Striga hermonthica (Del.) Benth (Striga) is considered to be one of the major biological constraints to food production in sub-Saharan Africa, probably a more agricultural problem than insects, birds or plant diseases (Ejeta and Butler, 1993). Over the years, the problem of Striga infestation has intensified across regions in Sub-Saharan Africa for a number of reasons, including: deteriorating soil fertility, shortening of the fallow period, expansion of production into marginal lands with little nutrient input and an increasing trend towards continuous cultivation of one crop in place of the traditional rotation and inter-cropping systems. Striga severely affects an estimated 40 million hectares of land devoted to cereal production in West Africa alone, with additional 70 million hectares having moderate levels of infestation (Lagoke et al., 1991).

The annual yield losses due to Striga in the savanna regions alone are estimated to be worth US\$7 billion and detrimental to the lives of over 100 million people in Africa (Mboob, 1986). The effects are likely to be long lasting as Striga plants produce millions of tiny seeds that can stay viable in the soil for many years. In Ghana, Striga is a serious problem in areas north of latitude $9^{\circ} 30^{\prime} \mathrm{N}$, which represents about $57 \%$ of the total land area (Nyarko, 1986). The estimated yield losses amount to 4.1 million mega grams of grain in a year. The farm household systems in the northern parts of Ghana rank first in the production of the four major cereals across the country; namely: maize, rice, sorghum and millet (PPMED, 1993). But the production of the cereals is menaced by the threat of low productivity as a result of the parasitic weed, Striga hermonthica (Sauerborn, 1991). According to Sauerborn (1991), records of yield losses caused by Striga hermonthica in Northern Ghana in 1988 amount to $16 \%$ for maize, $31 \%$ for millet and $29 \%$ for sorghum, representing a total economic loss of US\$25 million for the three crops. Under heavy 
infestation, maize is more vulnerable to Striga parasitism than upland rice, sorghum and millet, with high losses in excess of $90 \%$ (Efron et al., 1989). Striga infestation can cause yield losses of $20-100 \%$ in maize, driving some farmers to give up cultivation of the crop entirely. Almost all the farm fields of every district in the northern parts of Ghana are infested with Striga. However, RungeMetzger et al. (1997) stated that the state of knowledge with respect to the severity of Striga infestation, its geographical distribution in northern Ghana and its current trend is still extremely unsatisfactory.

In spite of the problem of Striga infestation, the cultivation of maize cannot be halted, since the crop is a major source of food for the people of Ghana and Africa in general. Maize is a staple food that constitutes the main diet of many people in the tropical and subtropical Africa (Oyekan et al., 1990). Its importance has increased as it has replaced other food staples, particularly sorghum and millet (Smith et al., 1994) and it has also become a major source of cash for smallholder farmers (Smith et al., 1997). Maize is also the widely consumed staple food with increasing production in Ghana since 1965 (FAO, 2008; Morris et al., 1999). It is an important cereal produced in all the five agroecological zones of Ghana (Obeng-Bio et al., 2011). Analysis based on 1987 maize consumption data in Ghana showed that maize and maize based foods accounted for $10.8 \%$ of food expenditure by the poor and $10.3 \%$ of food expenditure by all income groups (SARI, 1996). Breeding for Striga tolerance in maize may improve the performance of the crop even under Striga infested conditions and hence, increase the yield of maize. The objective of this study was to screen the inbred and hybrid lines of maize for tolerance to Striga hermonthica in the Northern Guinea Savanna Agroecological Zone of Ghana.

\section{Materials and Methods}

\section{Land preparation, Planting and Experimental Design}

The experiments were conducted at the experimental field of the Savanna Agricultural Research Institute (SARI) in the Northern Region of Ghana. The land was prepared by ploughing, after which all debris were removed. Land demarcation was done using lining and pegs. The prepared land was leveled using a hoe before seeds of the genotypes were planted. Twenty six maize genotypes consisting of 12 inbred lines and 14 hybrids from West and Central African Maize Collaborative Network (WECAMAN), Boake, La Cote d'Ivoire, were obtained from the Savannah Agricultural Research Institute (SARI), Nyankpala of the Council for Scientific and Industrial Research (CSIR) and screened for tolerance to Striga hermonthica during the 2012 cropping season under field experimental conditions. The inbred lines used for the study were: 991222-1, 991222-2, 991228-1, 991226-34, 991233-1, 991233-2, 991233-3, 991238-1, 9030STR, 9450STR, 5057 (SUSC) and GH110-5 (a check), whilst the hybrids used were: 9916-2STR，9916-11STR，9914-14STR，9914-59STR, 9925-3STR，9925-4STR，9925-51STR，9925-49STR, 9922-13STR, 8425-8STR, CLH105STR $=87036 \mathrm{X}$ 88094, CLH109STR = 87036 X ENTRADA 29, CLH111 $\mathrm{STR}=9021-18$ X M131 and $8338-1$ (SUSC).

In this experiment, maize and Striga seeds were both planted at stake on the prepared plots using $1 \%$ germinable Striga seed-sand mixture based on predetermined $70 \%$ purity and $65 \%$ germination of the Striga seed according to the procedure of (IITA, 1991). In the field studies, there were non-striga inoculated plants which served as the control plants. The inbred treatments were replicated three times in each case in the chosen designs, while the hybrid lines were replicated four times. Fine sand, sieved through a $250 \mu \mathrm{m}$ sieve was used to formulate the $1 \%$ germinable Striga seedsand mixture. The sand-Striga mixture was applied at approximately 2,500 germinable Striga seeds to each maize hole. The intensity of Striga infection on the individual maize genotypes was then assessed visually and scores attached to the various maize genotypes. The implication is that a genotype that scores/rates 1 or 2 is tolerant to Striga. A score/rate of 3 or higher indicates susceptibility of genotype to Striga infestation.

\section{Cultural Practices}

Basal fertilizer was applied at 2 weeks after planting at the rate of $30 \mathrm{~kg} \mathrm{~N} \mathrm{ha}^{-1}$ and $60 \mathrm{~kg} \mathrm{P}_{2} \mathrm{O}_{5} \mathrm{ha}^{-1}$. Plants were also top-dressed with additional $\mathrm{N}$ at $30 \mathrm{~kg} \mathrm{~N}^{-1}$ at 4 weeks after planting. Pre-emergence chemical weed control was used. An application of a combination of Pendimethalin [N- (1- ethylpropyl) - 3, 4-dimethyl -2, 6 - dinitrobenzenamine] and Gesaprim [2- chloro -4 (ethylamino) -6- (isopropylamino) -5- triazine] at a rate of $1.5 \mathrm{l} \mathrm{ha}^{-1}$ and $1.01 \mathrm{ha}^{-1}$ were used at planting. Where there was heavy weed growth prior to planting, Paraquat (1, 1- dimethyl -4, 4- bipyridinium ion) was also applied at $1.01 \mathrm{ha}^{-1}$ in addition to Pendimethalin and Gesaprim. Hand weeding was also carried out to keep the experimental field free of weeds at 4 weeks after planting.

\section{Data Collection and Analysis}

Measurements were made of growing crop parameters between flowering and physiological maturity for the field studies during the 2012 cropping season. These parameters include: plant height, days to $50 \%$ pollen shed, days to $50 \%$ silking, ear height, Striga count at 8 and 10 weeks, Striga plant rating at 10 weeks, plant stand, stem lodging and grain yield. The data collected were subjected to Analysis of Variance (ANOVA) using Genstat statistical package and means 
separated using the Least Significant Difference (LSD) at $5 \%$ level of probability.

\section{Results and Discussion}

Among the inbred lines in the Striga- infested plots, GH110-5 was the tallest $(88.33 \mathrm{~cm})$, followed by 991222-2 $(77.67 \mathrm{~cm}), 991228-1(74.33 \mathrm{~cm})$ and $991222-$ $1(70.00 \mathrm{~cm})$, whilst $991238-1$ was the shortest $(52.00$ $\mathrm{cm}$ ) (Table 1). However, there were no significant differences ( $>0.05)$ among GH110-5, 991222-2, 991228-1 and 991222-1. For plant height of the noninfested inbred plants, the genotype GH110-5 again was the tallest $(124.33 \mathrm{~cm})$. Whilst $991226-34$ was the shortest $(57.67 \mathrm{~cm})$. However, there were no significant differences $(\mathrm{p}>0.05)$ in plant height among GH110-5, 991222-2, 991222-1, 9030 STR, 5057 (SUSC), 9912281, 991233-3 and 991233-2 (Table 1).For the combined analysis of plant height among the inbred lines, GH1105 was again the tallest $(106.33 \mathrm{~cm})$, whilst 991226-34 was the shortest $(55.17 \mathrm{~cm})$. However, there were no significant differences ( $>0.05)$ among GH110-5, 991222-2, 991222-1 and 991228-1 (Table 1).The results also showed that all the inbred lines grown in the infested plots were shorter than those grown in the noninfested plots (Table 1).

The study revealed significant differences $(\mathrm{p}<0.01)$ in plant heights among the infested (Table 2) and noninfested inbred lines (Table 3). The differences in plant height may not have been attributed only to differences in levels of soil fertility of the experimental field and variation of host plant resistant mechanisms but also germination or haustorial initiation of Striga. In most infertile soils, Striga number goes down most probably due to fewer attachment sites on a malnourished host to sustain as much parasite (Ikie et al., 2007; Ransom et al., 1999). Stewart and Press (1990) also reported that Striga germination, attachment and haustorial formation all are dependent on Striga seeds receiving chemical cues from host roots. Siame et al. (1993) further observed that the major Striga germinating stimulant from maize and sorghum is sorgolactone and the minor stimulants are structurally related to strigol. It is therefore possible that all these stimulants were produced by some of the cultivars causing Striga seeds to germinate. The results of the study indicated that most of the genotypes grown in the infested plots were shorter than their counterpart in the non-infested plots (Table 1). The observation made here is a clear manifestation that Striga hermonthica had caused reduction in the growth of the host plants as a result of reduction in photosynthetic capacity to less than half of that occurring in healthy plants (Press and Graves, 1991). It is estimated that this reduction in photosynthesis in the host results in $80-85 \%$ growth reduction in infested maize and sorghum, whilst $20 \%$ of the damage is as a result of the actual removal of carbon by the parasite (Graves et al., 1989; 1990). Striga might have also acted not only as an additional sink but probably also had a strong 'toxic' or 'pathological' effect on the host and hence causing the reduction in growth and development of the host. Graves et al. (1989) stated that this parasitic plant induces reduction in host photosynthesis and this has been the most important mechanism of growth reduction. The authors also reported that about $80 \%$ of the decrease in host growth rate could be attributed to the impact Striga has on host photosynthesis.

The results showed that the genotype, 991228-1, took a maximum of 78 days to produce silk among the infested inbred plants, followed by 991233-2 (73 days), 991238-1(73 days) and 991233-1 (71 days). A minimum of 25 days was taken by 9030 STR to silk. The genotypes 991222-1 and 5057 (SUSC) in the infested plot did not produce silk (Table 1). The failure of some of the genotypes to produce silk might be due to the problem of susceptibility to Striga and/or low soil fertility. For the non-infested inbred lines, the results indicated that the highest number of days for silk production was produced by 5057 (SUSC) (74 days), whilst the lowest number of 24 days was produced by 991226-34 (Table 1). In general, silk production was better in the non-infested inbred lines than their infested counter parts. For the combined analysis of the days to $50 \%$ silking, $991228-1$ took the highest of 74 days to silk, followed by 991233-2, 991238-1, 991233-1 and GH110-5, with 69 days, 68 days, 68 days and 66 days respectively. The genotype 991226-34 took the lowest days of 26 to produce silk. However, there were no significant differences ( $>0.05)$ among 991228-1, 991233-2, 991238-1, 991233-1, GH110-5, 9450 STR, 991233-3 and 991222-2.

Among the Striga- infested hybrids, the observation was that the genotypes 9925-51 STR and 8338-1 (SUSC) took a maximum of 68 days each for $50 \%$ silking, followed by 9916-2 STR (67 days), CLH111 STR (67 days), CLH105 STR (67 days) and CLH 109 STR (66 days). However, a minimum of 64 days each was taken by 9925-4 STR and 9914-14 STR to produce silk (Table 4). There were however, no significant differences (p>0.05) among 9925-4 STR, 9914-14 STR, 8425-8 STR, 9925-49 STR, 9916-11 STR, 9925-3 STR, 9922-13 STR and 9914-59 STR. It was also observed that CLH111 STR took a maximum of 66 days for silk production among the non-infested hybrids, whilst a minimum of 63 days each was taken by 9925-4 STR, 9922-13 STR, 9914-59 STR, 9914-14 STR, 8425-8 STR, 9925-49 STR, 9925-3 STR and 9916-11 STR (Table 4). Silk production was generally more encouraging in the entire non-infested plots than in the infested plots. For the combined analysis of days to $50 \%$ silking among the hybrids, CLH111 STR and 9925-51 STR took a maximum of 67 days each, whilst a minimum of 63 days each was taken by 9925-4 STR and 9914-14 STR for silk production. 
Table 1. Trends in plant height, days to $50 \%$ silking and days to $50 \%$ pollen shed of maize inbred lines during screening under field conditions in 2012 cropping season

\begin{tabular}{|c|c|c|c|c|c|c|c|c|c|}
\hline \multirow[b]{2}{*}{ Genotype } & \multicolumn{3}{|c|}{ Plant Height $(\mathrm{cm})$} & \multicolumn{3}{|c|}{ Days to $50 \%$ Silking } & \multicolumn{3}{|c|}{ Days to $50 \%$ Pollen shed } \\
\hline & Infested & $\begin{array}{l}\text { Non- } \\
\text { Infested }\end{array}$ & Combined & Infested & $\begin{array}{l}\text { Non- } \\
\text { Infested }\end{array}$ & Combined & Infested & $\begin{array}{l}\text { Non- } \\
\text { Infested }\end{array}$ & Combined \\
\hline $991222-1$ & 70.00 & 115.67 & 92.83 & - & 73 & 36 & 51 & 70 & 61 \\
\hline $991222-2$ & 77.67 & 117.00 & 97.33 & 27 & 72 & 50 & 74 & 69 & 71 \\
\hline $991228-1$ & 74.33 & 107.33 & 90.83 & 78 & 69 & 74 & 70 & 65 & 68 \\
\hline $991226-34$ & 52.67 & 57.67 & 55.17 & 27 & 24 & 26 & 50 & 46 & 48 \\
\hline $991233-1$ & 63.33 & 89.67 & 76.50 & 71 & 65 & 68 & 66 & 63 & 64 \\
\hline $991233-2$ & 69.00 & 95.33 & 82.17 & 73 & 65 & 69 & 70 & 65 & 67 \\
\hline $991233-3$ & 61.67 & 97.00 & 79.33 & 27 & 74 & 50 & 79 & 70 & 75 \\
\hline $991238-1$ & 52.00 & 71.67 & 61.83 & 73 & 63 & 68 & 62 & 60 & 61 \\
\hline $9030 \mathrm{STR}$ & 63.00 & 110.33 & 86.67 & 25 & 72 & 48 & 73 & 68 & 70 \\
\hline 9450 STR & 63.67 & 90.33 & 77.00 & 54 & 68 & 61 & 68 & 65 & 67 \\
\hline 5057 (SUSC) & 56.33 & 109.67 & 83.00 & - & 74 & 37 & 49 & 70 & 59 \\
\hline GH110-5 & 88.33 & 124.44 & 106.33 & 69 & 63 & 66 & 64 & 61 & 62 \\
\hline $\operatorname{LSD}(0.05)$ & 18.89 & 30.44 & 17.62 & 44 & 21 & 25 & 37 & 20 & 20 \\
\hline
\end{tabular}

Infested genotypes that recorded '- 'did not produce silk

Table 2. Mean squares and Co-Efficient of Variation (CV \%) for plant height, days to $50 \%$ pollen shed, days to $50 \%$ silking, Striga plant count at 8 and 10 weeks and plant stand of inbred lines under Striga-infested conditions

\begin{tabular}{llllcccc}
\hline Source & df & $\begin{array}{l}\text { Days to } \\
50 \% \text { Silking }\end{array}$ & $\begin{array}{l}\text { Days to 50\% } \\
\text { Pollen Shed }\end{array}$ & $\begin{array}{l}\text { Striga Count } \\
\text { at 8 Weeks }\end{array}$ & $\begin{array}{l}\text { Striga Count } \\
\text { at 10 Weeks }\end{array}$ & $\begin{array}{l}\text { Plant } \\
\text { Stand }\end{array}$ & $\begin{array}{c}\text { Plant } \\
\text { Height (cm) }\end{array}$ \\
\hline Replication & 2 & 3287.53 & 587.03 & 3.58 & 0.36 & 7.69 & 1281.08 \\
Entry & 11 & $2560.57^{* *}$ & $292.69^{\text {ns }}$ & $5.09^{* *}$ & $0.32^{* *}$ & $23.81^{\text {ns }}$ & $337.33^{* *}$ \\
Error & 22 & 671.04 & 469.12 & 2.04 & 0.09 & 13.94 & 124.42 \\
CV \% & & 59.360 & 33.51 & 14.13 & 6.22 & 28.84 & 16.90 \\
\hline
\end{tabular}

${ }^{*}$ Significant at $\mathrm{p}<0.05,{ }^{* *}$ Significant at $\mathrm{p} 0.01,{ }^{\text {ns }}$ Non-significant at $\mathrm{p}>0.05$

Table 3. Mean squares and Co-efficient of Variation (CV) for plant height, days to $50 \%$ silking, days to $50 \%$ pollen shed, grain yield, plant stand, ear height and stem lodging of the inbred lines under non-infested conditions

\begin{tabular}{lcclllllc}
\hline & & Plant & Days to & Days to & Grain & Plant & Ear & \\
Source & df & Height $(\mathrm{cm})$ & $50 \%$ Silking & $50 \%$ Pollen Shed & Yield (tons/ha) & Stand & Height $(\mathrm{cm})$ & Lodging \\
\hline Replication & 2 & 163.00 & 80.03 & 149.33 & 0.05 & 68.25 & 38.11 & 0.44 \\
Entry & 11 & $1142.76^{* *}$ & $552.86^{* *}$ & $136.15^{\text {ns }}$ & $0.45^{* * *}$ & $51.83^{* *}$ & $233.78^{* *}$ & $0.27^{\text {ns }}$ \\
Error & 22 & 323.12 & 153.45 & 133.03 & 0.02 & 17.46 & 63.63 & 0.17 \\
CV \% & & 18.19 & 19.03 & 17.97 & 37.03 & 28.33 & 21.49 & 13.11 \\
\hline
\end{tabular}

${ }^{*}$ Significant at $\mathrm{p}<0.05,{ }^{* *}$ Significant at $\mathrm{p}<0.01,{ }^{* * *}$ Significant at $\mathrm{p}<0.001,{ }^{\mathrm{ns}}$ Non-significant at $\mathrm{p}>0.05$

Table 4. Variation in plant height, days to $50 \%$ silking and grain yield of hybrid lines during screening under field conditions in 2012 cropping season

\begin{tabular}{|c|c|c|c|c|c|c|c|c|c|}
\hline \multirow[b]{2}{*}{ Genotype } & \multicolumn{3}{|c|}{ Plant Height $(\mathrm{cm})$} & \multicolumn{3}{|c|}{ Grain Yield (tons/ha) } & \multicolumn{3}{|c|}{ Days to $50 \%$ Silking } \\
\hline & Infested & $\begin{array}{l}\text { Non- } \\
\text { Infested }\end{array}$ & Combined & Infested & $\begin{array}{l}\text { Non- } \\
\text { Infested }\end{array}$ & Combined & Infested & $\begin{array}{l}\text { Non- } \\
\text { Infested }\end{array}$ & Combined \\
\hline 9916-2 STR & 141.00 & 171.00 & 156.00 & 1.25 & 3.15 & 2.19 & 67 & 64 & 66 \\
\hline 9916-11 STR & 149.50 & 167.25 & 158.38 & 1.47 & 2.64 & 2.05 & 65 & 63 & 64 \\
\hline 9914-14 STR & 135.75 & 163.25 & 149.50 & 1.84 & 3.20 & 2.53 & 64 & 63 & 63 \\
\hline 9914-59 STR & 110.00 & 148.00 & 129.00 & 1.39 & 2.40 & 1.87 & 66 & 63 & 64 \\
\hline 9925-3 STR & 128.25 & 143.00 & 135.63 & 1.47 & 1.89 & 1.68 & 65 & 63 & 64 \\
\hline 9925-4 STR & 120.75 & 138.75 & 129.75 & 1.47 & 2.13 & 1.81 & 64 & 63 & 63 \\
\hline 9925-51 STR & 144.50 & 176.50 & 160.50 & 1.25 & 2.37 & 1.81 & 68 & 65 & 67 \\
\hline 9925-49 STR & 129.50 & 158.00 & 143.75 & 1.52 & 2.67 & 2.08 & 65 & 63 & 64 \\
\hline 9922-13 STR & 123.25 & 154.50 & 138.88 & 1.47 & 2.72 & 2.08 & 66 & 63 & 64 \\
\hline 8425-8 STR & 121.50 & 146.50 & 134.00 & 1.63 & 2.72 & 2.16 & 64 & 63 & 64 \\
\hline CLH105 STR & 158.75 & 181.50 & 170.13 & 1.63 & 2.32 & 1.97 & 67 & 65 & 66 \\
\hline CLH109 STR & 145.50 & 171.00 & 158.25 & 1.71 & 2.40 & 2.05 & 66 & 65 & 66 \\
\hline CLH111 STR & 141.25 & 154.75 & 148.00 & 1.68 & 1.79 & 1.73 & 67 & 66 & 67 \\
\hline 8338-1(SUSC) & 129.25 & 170.00 & 149.63 & 0.99 & 2.40 & 1.68 & 68 & 64 & 66 \\
\hline $\operatorname{LSD}(0.05)$ & 13.280 & 13.22 & 12.12 & 0.45 & 0.72 & 0.61 & 3 & 2 & 2 \\
\hline
\end{tabular}


Table 5. Mean squares and Co-Efficient of Variation (CV \%) for of plant height, grain yield, days to 50\% silking, days to $50 \%$ pollen shed, Striga plant rating and Striga plant count of hybrid maize under Striga-infested conditions

\begin{tabular}{lcccccccc}
\hline Source & df & $\begin{array}{l}\text { Plant } \\
\text { Height }(\mathrm{cm})\end{array}$ & $\begin{array}{l}\text { Grain Yield } \\
\text { (tons/ha) }\end{array}$ & $\begin{array}{l}\text { Days to } \\
\text { 50\% Silking }\end{array}$ & $\begin{array}{l}\text { Days to 50\% } \\
\text { Pollen Shed }\end{array}$ & $\begin{array}{l}\text { Striga Count } \\
\text { at 8 weeks }\end{array}$ & $\begin{array}{l}\text { Striga } \text { Count } \\
\text { at 10 weeks }\end{array}$ & $\begin{array}{l}\text { Striga } \text { Plant } \\
\text { Rating at 10 weeks }\end{array}$ \\
\hline Replication & 3 & 707.26 & 0.11 & 10.33 & 7.76 & 11.17 & 60.41 & 1.64 \\
Entry & 13 & $707.28^{* * *}$ & $0.03^{\text {ns }}$ & $9.45^{* * *}$ & $4.92^{* * *}$ & $20.23^{* *}$ & $43.04^{\text {ns }}$ & $0.53^{* *}$ \\
Error & 39 & 86.27 & 0.01 & 3.26 & 1.39 & 10.15 & 26.56 & 0.19 \\
CV \% & & 6.92 & 21.46 & 2.74 & 1.89 & 84.97 & 66.50 & 11.97 \\
\hline
\end{tabular}

${ }^{*}$ Significant at $\mathrm{p}<0.05,{ }^{* *}$ Significant at $\mathrm{p}<0.01,{ }^{* * *}$ Significant at $\mathrm{p}<0.001,{ }^{\text {ns }}$ Non-significant at $\mathrm{p}>0.05$

Table 6. Mean squares and Co-Efficient of Variation (CV \%) for of plant height, grain yield, days to $50 \%$ silking, days to $50 \%$ pollen shed and ear height of hybrid maize under non-infested conditions

\begin{tabular}{|c|c|c|c|c|c|c|}
\hline Source & $\mathrm{df}$ & $\begin{array}{l}\text { Plant } \\
\text { Height }(\mathrm{cm})\end{array}$ & $\begin{array}{l}\text { Grain Yield } \\
\text { (tons/ha) }\end{array}$ & $\begin{array}{l}\text { Days to } \\
50 \% \text { Silking }\end{array}$ & $\begin{array}{l}\text { Days to } \\
50 \% \text { Pollen shed }\end{array}$ & Ear Height $(\mathrm{cm})$ \\
\hline$\overline{\text { Replication }}$ & 3 & 1205.48 & 0.88 & 0.49 & 0.21 & 392.05 \\
\hline Entry & 13 & $697.57^{* * *}$ & $0.09^{* *}$ & $4.62^{* * *}$ & $2.96^{* *}$ & $275.90^{* * *}$ \\
\hline Error & 39 & 85.4 & 0.04 & 1.06 & 1.15 & 45.71 \\
\hline CV \% & & 5.77 & 20.31 & 1.61 & 1.74 & 9.34 \\
\hline
\end{tabular}

${ }^{*}$ Significant at $\mathrm{p}<0.05,{ }^{* *}$ Significant at $\mathrm{p}<0.01,{ }^{* * *}$ Significant at $\mathrm{p}<0.001,{ }^{\text {ns }}$ Non-significant at $\mathrm{p}>0.05$

Table 7. Pearson correlation co-efficients

\begin{tabular}{|c|c|c|c|c|c|c|}
\hline & $\begin{array}{l}\text { Days to } \\
50 \% \text { silking }\end{array}$ & $\begin{array}{l}\text { Days to } 50 \% \\
\text { pollen shed }\end{array}$ & $\begin{array}{l}\text { Plant } \\
\text { height }\end{array}$ & $\begin{array}{l}\text { Striga plant } \\
\text { rating at } 10 \text { weeks }\end{array}$ & $\begin{array}{l}\text { Striga count at } \\
8 \text { weeks }\end{array}$ & $\begin{array}{l}\text { Striga count } \\
\text { at } 10 \text { weeks }\end{array}$ \\
\hline Grain yield & $-0.6244^{* *}$ & $-0.3480^{* *}$ & $0.4190^{* *}$ & $-0.5360^{* * *}$ & $0.0500^{\mathrm{ns}}$ & $0.0680^{\mathrm{ns}}$ \\
\hline Days to $50 \%$ silking & & $0.7740^{* * *}$ & $-0.0760^{\mathrm{ns}}$ & $0.3820^{* *}$ & $0.0410^{\mathrm{ns}}$ & $0.0960^{\mathrm{ns}}$ \\
\hline Days to $50 \%$ pollen shed & & & $0.0077^{\mathrm{ns}}$ & $0.3460^{* *}$ & $0.0930^{\mathrm{ns}}$ & $0.0099^{\mathrm{ns}}$ \\
\hline Plant height & & & & $-0.5130^{* * *}$ & $0.0366^{\mathrm{ns}}$ & $0.0002^{\mathrm{ns}}$ \\
\hline Striga plant rating at 10 weeks & & & & & $0.0847^{\mathrm{ns}}$ & $0.1017^{\mathrm{ns}}$ \\
\hline Striga count at 8 weeks & & & & & & $0.8740^{* * *}$ \\
\hline
\end{tabular}

${ }^{*}$ Significant at $\mathrm{p}<0.05,{ }^{* *}$ Significant at $\mathrm{p}<0.01,{ }^{* * *}$ Significant at $\mathrm{p}<0.001,{ }^{\mathrm{ns}}$ Non-significant at $\mathrm{p}>0.05$

Table 8. Variation in plant stand, Striga plant count, Striga plant rating and grain yield of inbred lines during screening under field conditions in 2012 cropping season

\begin{tabular}{llllllll}
\hline Genotype & $\begin{array}{l}\text { Plant Stand } \\
\text { Infested }\end{array}$ & $\begin{array}{l}\text { Non- } \\
\text { infested }\end{array}$ & $\begin{array}{l}\text { Combined } \\
\text { Ctriga Count } \\
\text { at weeks }\end{array}$ & $\begin{array}{l}\text { Striga Count at } \\
10 \text { weeks }\end{array}$ & $\begin{array}{l}\text { Striga Plant } \\
\text { Rating at 10 weeks }\end{array}$ & $\begin{array}{l}\text { Grain Yield } \\
\text { (tons/ha) (non-infested) }\end{array}$ \\
\hline $991222-1$ & 18 & 9 & 14 & 0 & 5 & 5 & 0.16 \\
$991222-2$ & 15 & 13 & 14 & 1 & 5 & 5 & 0.72 \\
$991228-1$ & 12 & 17 & 15 & 0 & 5 & 5 & 0.80 \\
$991226-34$ & 14 & 7 & 11 & 0 & 5 & 5 & 0.19 \\
$991233-1$ & 12 & 16 & 14 & 1 & 4 & 4 & 0.80 \\
$991233-2$ & 10 & 16 & 13 & 0 & 5 & 5 & 0.80 \\
$991233-3$ & 8 & 10 & 9 & 0 & 5 & 5 & 0.88 \\
$991238-1$ & 11 & 18 & 15 & 0 & 5 & 5 & 0.72 \\
9030 STR & 10 & 18 & 14 & 0 & 5 & 5 & 0.80 \\
9450 STR & 14 & 16 & 15 & 0 & 5 & 5 & 0.99 \\
5057(SUSC) & 13 & 19 & 16 & 1 & 5 & 5 & 4.27 \\
GH110-5 & 16 & 19 & 18 & 5 & 4 & 4 & 0.64 \\
LSD (0.05) & 6 & 7 & 5 & 2 & 1 & 0 & \\
\hline
\end{tabular}

However, there were no significant differences $(\mathrm{p}>0.05)$ among the genotypes 9925-4 STR, 9914-14 STR, 8425-8 STR, 9925-49 STR, 9916-11 STR, 9925-3 STR, 9922-13 STR and 9914-59 STR (Table 4).

Days required for silking along with other maturity traits are commonly used by plant breeders as basis of determining maturity of maize. The study established highly significant differences $(p<0.001)$ in the number of days for silk production among genotypes within the infested (Table 5) and non-infested (Table 6) hybrid maize.
The infested genotypes generally took higher number of days to reach silking than non-infested genotypes (Table 4). The Striga infestation could have induced the prolonged period of silking among the infested plants. The observed trend in silking among the Striga infested genotypes could be attributed to differences in the levels of Striga tolerance among the infested genotypes. Silk production was generally more encouraging in the noninfested plots than in the infested plots. To aid the selection process, it is always essential to have the 
information on nature of association of characters with economic yield. The data for correlation studies at the phenotypic level showed that grain yield exhibited negative and significant $(\mathrm{p}<0.01)$ correlation with days to $50 \%$ silking (Table 7 ). This implies that grain yield is likely to increase with decrease in days to silking. This finding corroborates the observation made by Banziger et al. (1999) that days to silking and anthesissilking interval are important traits that influence maize yield under serious stress.

The study established that the genotype 9916-14 STR produced the highest grain yield of 1.84 tons/ha among the infested hybrids. It was followed by the genotypes CLH109 STR (1.71 tons/ha), CLH111 STR (1.68 tons/ha) and CLH 105 STR (1.63 tons/ha). However, the genotype 8338-1 (SUSC) produced the lowest grain yield of 0.99 tons/ha (Table 4). There were no significant differences ( $p>0.05)$ among 9914-14 STR, CLH109 STR, CLH111 STR, CLH105 STR, 8425-8 STR, 992549 STR, 9916-11 STR, 9922-13 STR, 9925-3 STR and 9925-4 STR for grain yield. In the non-infested hybrid plots, 9914-14 STR produced the highest grain yield of 3.20 tons/ha. It was closely followed by $9916-2$ STR, 8425-8 STR, 9922-13 STR and 9925-49 STR with grain yield of 3.15 tons/ha, 2.72 tons/ha, 2.72 tons/ha and 2.67 tons/ha, respectively. The lowest grain yield of 1.79 tons/ha was produced by CLH 111 STR (Table 4). However, there were no significant differences $(\mathrm{p}>0.05)$ among 9914-14 STR, 9916-2 STR, 8425-8 STR, 992213 STR, 9925-49 STR and 9916-11 STR for grain yield. The grain yield produced in the non-infested plots was higher than those in the infested plots (Table 4). For the combined analysis of grain yield, the hybrid 9914-14 STR produced the highest grain yield of 2.53 tons/ha, whilst 9925-3 STR produced the lowest grain yield of 1.68 tons/ha. There were however, no significant differences ( $>0.05$ ) in terms of grain yield among 9914-14 STR, 9916-2 STR, 8425-8 STR, 9925-49 STR, 9922-13 STR, CLH109 STR, 9916-11 STR and CLH105 STR.

Maximum grain yield is the prime objective in most breeding programs. The results revealed a clear impact of Striga infection on grain yield. There was a significant $(\mathrm{p}<0.05)$ variation in grain yield among the non-infested as well as the Striga-infested hybrids. The yields produced in the non-infested plots were generally higher than those in the infested plots. There was also a statistical difference $(p<0.05)$ in grain yield among the non-infested inbred lines. In general, grain yield is determined by the levels of tolerance of the host genotype, by severity of infestation and/or by the levels of soil fertility. Kim et al. (2002) reported that tolerant varieties suffer lower yield reduction and often produce 2 - 2.5 times the yield of susceptible varieties, especially under high infestation. Okonkwo (1966) attributed grain yield losses to the diversion of photosynthates, mineral salts and water from the host to the parasite. The data for correlation studies at the phenotypic level showed that grain yield exhibited positive and significant $(p<0.01)$ correlation with plant height (Table 7). This implies that grain yield is likely to increase with increase in plant height. However, the correlation studies established that grain yield exhibited negative and significant $(p<0.001)$ correlation with Striga plant rating. This implies that grain yield is likely to increase with decrease in Striga plant rating.

The grain yield for inbred lines grown in the noninfested plots showed that genotype GH110-5 produced the highest grain yield (4.27 tons/ha), this was followed by 5057 (SUSC) (0.99 tons/ha), 991233-2 (0.88 tons/ha), 9938-1 (0.88 tons/ha) and 991233-1 (0.80 tons/ha). Genotype 991226-34 produced the lowest grain yield of 0.19 tons/ha (Table 8 ). There was a significant difference $(\mathrm{p}<0.05)$ between GH110-5 and all the other genotypes. No grain yield was produced from the infested plots. The infestation of the field with Striga might have contributed to the zero grain yields of the inbred lines.

Among the inbred maize, genotypes GH110-5 and 991233-1 had equal Striga plant rating of 4 (Table 8). This means that their ability to tolerate Striga was equal. The rating of the other genotypes was 5 each. This indicates that GH110-5 and 991233-1 are more tolerance to Striga than the rest of the genotypes.

Results from the mean Striga plant rating of the infested hybrids indicated that ten of the hybrid genotypes: 9916-2 STR, 8338-1 (SUSC), 9922-13 STR, 9914-59 STR, CLH111 STR, 9916-11 STR, 9925-4 STR, 9925-51 STR, 9925-49 STR and 8425-8 STR were rated 4 , whilst the rest of the genotypes were rated 3 (Table 9). The implication is that all the genotypes that were rated lower are more tolerant to Striga than those with higher rating.

Adeosun et al. (2001) had described Striga emergence and Striga count as parameters to assess the tolerance level of crop genotypes. However, Kim (1994) recommended the use of Striga rating in assessing crop genotypes for tolerance to Striga infestation. The study showed a significant variation among Striga infested genotypes for Striga rating, which could have been attributed to variation in the ability of the plants to resist Striga infestation. Ejeta et al. (1999) reported that the development of necrotic lesions on the root of maize causes poor development leading to the death of attached Striga on the host. Lynn and Chang (1990) also observed that the high tolerance to Striga of some genotypes may be due to the low production of host plant root exudate compounds that are essential for Striga seed germination. The study further showed that Striga plant rating was negatively and highly significantly associated $(\mathrm{p}<0.001)$ with grain yield (Table 7). The implication is that grain yield is likely to increase with a decrease in Striga plant rating. 
Table 9. Variation in days to $50 \%$ pollen shed, ear height, Striga plant count, Striga plant rating of the hybrid maize during screening under field conditions in 2012

\begin{tabular}{|c|c|c|c|c|c|c|c|}
\hline \multirow[b]{2}{*}{ Genotype } & \multicolumn{3}{|c|}{ Days to $50 \%$ Pollen Shed } & \multirow[b]{2}{*}{$\begin{array}{l}\text { Ear Height }(\mathrm{cm}) \\
\text { (non-infested) }\end{array}$} & \multirow[b]{2}{*}{$\begin{array}{l}\text { Striga Count } \\
\text { at } 8 \text { weeks }\end{array}$} & \multirow[b]{2}{*}{$\begin{array}{l}\text { Striga Count } \\
\text { at } 10 \text { weeks }\end{array}$} & \multirow[b]{2}{*}{$\begin{array}{l}\text { Striga Plant } \\
\text { Rating at } 10 \text { weeks }\end{array}$} \\
\hline & Infested & $\begin{array}{l}\text { Non- } \\
\text { infested }\end{array}$ & Combined & & & & \\
\hline 9916-2 STR & 63 & 62 & 62 & 78.75 & 4 & 7 & 4 \\
\hline 9916-11 STR & 62 & 61 & 61 & 77.50 & 5 & 9 & 4 \\
\hline 9914-14 STR & 61 & 61 & 61 & 70.25 & 7 & 14 & 3 \\
\hline 9914-59 STR & 62 & 61 & 62 & 60.75 & 2 & 7 & 4 \\
\hline 9925-3 STR & 62 & 62 & 62 & 67.75 & 1 & 5 & 3 \\
\hline 9925-4 STR & 61 & 61 & 61 & 59.00 & 2 & 4 & 4 \\
\hline 9925-51 STR & 65 & 63 & 64 & 87.00 & 3 & 5 & 4 \\
\hline 9925-49 STR & 62 & 61 & 61 & 69.75 & 2 & 4 & 4 \\
\hline 9922-13 STR & 62 & 61 & 62 & 71.00 & 3 & 6 & 4 \\
\hline 8425-8 STR & 61 & 61 & 61 & 66.25 & 3 & 8 & 4 \\
\hline CLH105 STR & 62 & 62 & 62 & 83.00 & 3 & 8 & 3 \\
\hline CLH109 STR & 63 & 62 & 63 & 82.25 & 4 & 10 & 3 \\
\hline CLH111 STR & 64 & 63 & 64 & 72.75 & 5 & 10 & 4 \\
\hline 8338-1(SUSC) & 62 & 61 & 62 & 68.00 & 9 & 14 & 4 \\
\hline $\operatorname{LSD}(0.05)$ & 2 & 2 & 1 & 9.67 & 5 & 7 & 1 \\
\hline
\end{tabular}

The study indicated that among the Striga-infested hybrid plots, the genotype 9925-51 STR took 65 days to shed pollen, this was followed by CLH111 STR (64 days), CLH109 STR (63 days) and 9916-2 STR (63 days). Whilst the lowest of 61 days each was taken by 9914-14 STR, 8425-8 STR and 9925-4 STR to shed pollen (Table 9). There were no significant differences ( $>0.05$ ) among 9914-14 STR, 8425-8 STR, 9925-4 STR, 9925-49 STR, 9916-11 STR, 9925-3 STR, 9914-59 STR, 9922-13 STR, CLH105 STR and 8338-1(SUSC). For days to $50 \%$ pollen shed among the non-infested hybrid maize, the genotypes CLH111 STR and 9925-51 STR took a maximum of 63 days each, whilst 9916-11 STR, 9914-14 STR, 9925-49 STR and 9925-4 STR took a minimum of 61 days each to shed pollen. However, there were no significant differences $(\mathrm{p}>0.05)$ among 9916-11 STR, 9914-14 STR, 9925-49 STR, 9925-4 STR, 9922-13 STR, 9914-59 STR, 8425-8 STR, 83381(SUSC), 9925-3 STR, 9916-2 STR and CLH109 STR (Table 9). The number of days to $50 \%$ pollen shed was generally higher for all the hybrids in the Striga-infested plots than in the non-infested plots. The disparity in the number of days to $50 \%$ pollen shed could be attributed to the Striga infestation. In the combined analysis of days to $50 \%$ pollen shed, $9925-51$ STR and CLH111 STR took 64 days to shed pollen, while 9914-14 STR, 9925-4 STR, 8425-8 STR, 9916-11 STR and 9925-49 STR took 61 days each to shed pollen. There were no significant differences ( $\mathrm{p}>0.05)$ among 9914-14 STR, 9925-4 STR, 8425-8 STR, 9916-11 STR, 9925-49 STR, 9914-59 STR, 9922-13 STR, 9925-3 STR and 8338-1 (SUSC) with regards to days to pollen shed. The data for correlation studies showed that grain yield exhibited negative and significant $(\mathrm{p}<0.01)$ correlation with days to $50 \%$ pollen shed (Table 7). This implies that grain yield is likely to increase with decrease in number of days to pollen shed.
The study established that among the non-infested hybrid maize, the genotype 9925-51 STR produced the highest ear height of $87 \mathrm{~cm}$, whilst the lowest ear height of $59 \mathrm{~cm}$ was produced by 9925-4 STR (Table 9). There were however no significant differences among the hybrids 9925-51 STR, 9916-2 STR, 9916-11 STR, CLH105 STR and CLH109 STR for ear height. The study established that the ear heights of the hybrid plants significantly $(p<0.05)$ varied from one genotype to the other among the non-infested plots. Ali et al. (2011) confirmed this and reported that shorter ear heights are generally not desirable. This is because the problem of crowded canopy, aeration and low transmission of sun light to the lower parts may result in drastic reduction in yield. The findings of Menyonga et al. (1987) were on the contrary. They observed that greater ear height is undesirable because the ear placement at a greater height from the ground level exerts pressure on plant during grain filling and physiological maturity and causes lodging, which could ultimately affect the final yield.

\section{Conclusion and Recommendations}

The experiment was conducted to screen maize inbred and hybrid lines for Striga tolerance. From the foregoing results and discussion of the experiment, the following conclusions were deduced:

The inbred lines (GH110-5, 991228-1 and 9912331) produced the best results with reference to plant height, days to $50 \%$ silking, days to $50 \%$ pollen shed, Striga plant rating and plant stand. Therefore, the three inbred lines are likely to be more tolerant to Striga than their counterparts.

The hybrid maize (9914-14STR, 8425-8STR, 992549STR, 9916-11STR, 9925-3STR, CLH105STR and 
CLH109STR) produced the best results with respect to grain yield, plant height, days to $50 \%$ silking, days to $50 \%$ pollen shed and Striga plant rating. Therefore, the seven hybrids are more tolerant to Striga than their counterparts. Based on the conclusions drawn, it is recommended that;

The cultivation of hybrid maize (9914-14STR, 84258STR, 9925-49STR, 9916-11STR, 9925-3STR, CLH105STR and CLH109STR) or their crosses on Striga infested agricultural land will result in increased yield.

\section{Acknowledgement}

We do acknowledge the critical comments and scientific inputs made by all researchers of the Department of Agronomy of the University for Development Studies, Tamale and the Savanna Agricultural Research Institute, Tamale, Ghana.

\section{Funding Information}

There was no external funding. Funding of the study was done by the authors.

\section{Author's Contributions}

All the three authors participated in the field study, data analysis and the entire process of the article preparation.

\section{Ethics}

There are no actual or potential conflicts of interest including financial, personal or other relationships with other people or organizations that could inappropriately influence, or be perceived to influence this work. Therefore, no ethical issue may arise after the publication of this article.

\section{References}

Adeosun, J.O., R.A. Gbadeges, J.Y. Shabeyan, D.A. Aba and P.O. Idris et al., 2001. Evaluation of sorghum cultivars for their resistance to Striga hermonthica. Moor J. Agric. Res., 2: 25-30.

Ali, F., M. Muneer, H. Rahman, M. Noor and Durrishahwar et al., 2011. Heritability estimates for yield and related traits based on testcross progeny performance of resistant maize inbred lines. J. Food Agric Environ., 9: 438-443.

Banziger, M., G.O. Edmeades and H.R. Lafitte, 1999. Selection for drought tolerance increases maize yields across a range of nitrogen levels. Crop Sci., 39: 1035-1040. DOI: 10.2135/cropsci1999.0011183X003900040012x
Efron, Y., S.K. Kim, V. Parkinson and N.A. BosquePerez, 1989. IITA's Strategies to Develop Striga Resistant Maize Germplasm. In: Striga-Improved Management in Africa: Proceedings, FAO/OAU AllAfrican Government Consultation on Striga Control, Maroua, Robinson, T.O. and H.R. Broad (Eds.), FAO Plant Production and Protection, pp: 141-153.

Ejeta, G. and L.G. Butler, 1993. Host plant resistance to Striga. Proceedings of the International Crop Science Congress. Crop Science Society of America. Madison, WI, pp: 561-569.

Ejeta, G., A. Mohammed, A. Melake-Berhan, P.R. Housley and D.E. Hess, 1999. Selection for specific mechanisms of resistance to Striga in sorghum.

FAO, 2008. Food and Nutrition Paper 55. FAO, Rome.

Graves, J.D., M.C. Press and G.R. Stewart, 1989. A carbon balance model of the sorghum-Striga hermonthica host-parasite association. Plant Cell Environ., 12: 101-107.

Graves, J.D., A. Wylde, M.C. Press and G.R. Stewart, 1990. Growth and carbon allocation in Pennisetum typhoides infected with the parasitic angiosperm Striga hermonthica. Plant Cell Environ., 13: 367-373.

IITA, 1991. Sustainable food production in sub-Saharan Africa: IIT A's contributions. International Institute of Tropical Agriculture, Ibadan, Nigeria, pp: 208.

Ikie, F.O., S. Schulz, S. Ogunyemi, A.M. Emechebe and A.O. Togun, 2007. Influence of legume cropping patterns and organic/inorganic soil amendments on Striga seedbank and subsequent sorghum performance. Advances Environ. Biology, 1: 11-19.

Kim, S.K., 1994. Genetics of maize tolerance to Striga hermonthica. Crop Sci., 34: 900-907. DOI: 10.2135/cropsci1994.0011183X003400040012x

Kim, S.K., V.O. Adetimirin, C. The and R. Dossou, 2002. Yield losses in maize due to Striga hermonthica in West and Central Africa. Int. J. Pest Management, 48: 211-217. DOI: $10.1080 / 09670870110117408$

Lagoke, S.T.O., V. Pakinson and R.M. Agunbiade, 1991. Parasitic Weed Control Methods in Africa. In: Combating Striga in Africa: Proceeding of International Workshop Organizes by IITA, S.K. (Ed.), ICRISAT and IDRC at IITA, Ibadan, Kim, Aug. 22-24. pp: 3-14.

Lynn, D.G. and M. Chang, 1990. Phenolic signals in cohabitation: Implications for plant development. Ann. Rev. Plant Physiol., 41: 497-526. DOI: 10.1146/annurev.pp.41.060190.002433

Mboob, S.S., 1986. A regional programme for West and Central Africa. Proceedings of the FAO/OAU AllAfrican Government Consultation on Striga Control, Oct. 20-24, Maroua, Cameroon, pp: 190-194.

Menyonga, J.M., B. Tay and Y. Anthony, 1987. Food grain production in semi-arid Africa. Proceedings of an International Drought Symposium Held at Kenyatta Conference Centre (KCC' 87), Nairobi, Kenya, pp: 191-208. 
Morris, M.L., J. Risopoulos and D. Beck, 1999. Genetic changes in farmer-recycled maize seed: A review of the evidence. CIMMYT Econ. Working Paper No. 99-07, Mexico.

Nyarko, A., 1986. Striga in Ghana. Proceedings of the FAO/OAU All-African Government Consultation on Striga Control, Oct. 20-24, Maroua, Cameroon, pp: 51-53.

Obeng-Bio, E., M. Bonsu, K. Obeng-Antwi and R. Akromah, 2011. Establishing the basis for drought tolerant Maize (Zea mays L.) using some secondary traits in the field. African J. Plant Sci., 5: 702-709. DOI: $10.5897 /$ AJPS11.113

Okonkwo, S.N.C., 1966. Studies on Striga senegalensis Benth. II. Translocation of ${ }^{14} \mathrm{C}$-labeled photosynthates, urea- ${ }^{14} \mathrm{C}$ and Sulpate- 35 between host and parasite. Am. J. Botany, 53: 142-148. DOI: $10.2307 / 2440080$

Oyekan, J., S.K. Vasil and D.L. Beck, 1990. CIMMYT's tropical late yellow maize germplasm. Maydica, 35: 273-278.

PPMED, 1993. Annual survey sample of agriculture 1992. Policy Planning Monitoring and Evaluation Division (Agricultural Statistics and Census Division), Ministry of Food and Agriculture, Accra, Ghana.

Press, M.C. and J.D. Graves, 1991. Carbon relations of angiosperm parasites and their hosts. Proceedings of the International Workshop on Orobanche Research, Aug. 19-22, Obermarchtal, Germany, pp: 55-65.

Ransom, J.K., J. Kroschel, H. Mercer-Quarshie and J. Sauerborn, 1999. The Status quo of Striga Control; Cultural, Chemical and Integrated Aspects. In: Advances in Parasitic Weed Control at on-Farm Level, vol. 1. Kroschel, J., H. Mercer-Quarshie and J. Sauerborn (Eds.), Margrave-verlag, Weikersheim, Germany, pp: 133-143.
Runge-Metzger, A., J. Kroschel and J. Sauerborn, 1997. The economics of Striga control in different farming systems in Northern Ghana, Proceedings of the 3rd General Workshop of the Pan-African Striga Control Network (PASCON). "Integrated Management of Striga for the African Farmer". Oct. 18-23, Harare, Zimbabwe. FAO Accra (Ghana), pp: 134-143.

SARI, 1996. Savanna Agricultural Research Institute. Annual Report.

Sauerborn, J., 1991. The economic importance of phytoparasites Orobanche and Striga. Proceedings of the 5th International Symposium on Parasitic Weeds. Ransom, J.K., L.J. Musselman, A.D. Worsham and C. Parker (Eds.), Nairobi, Kenya, Jun. 24-30, pp: 137-143.

Siame, B.A., Y. Weerasuriya, K. Wood, G. Ejeta and L.G. Butler, 1993. Isolation of strigol, a germination stimulant for Striga asiatica, from host plant. J. Agric. Food Chem., 41: 1486-1491. DOI: $10.1021 /$ jf00033a025

Smith, J., A.D. Barau, A. Goldman and J.H. Mareck, 1994. The role of technology in agricultural intensification: The evolution of maize production in the Northern Guinea Savanna of Nigeria. Econ. Dev. Cult. Change, 42: 537-554. DOI: 10.1086/452101

Smith, J., G. Weber, M.V. Manyong and M.A.B. Fakorede, 1997. Fostering sustainable increases in maize productivity in Nigeria. In: Africa's Emerging Maize Revolution, Eicher, C.K. and D. Byerlee (Eds.), Lynne Rienner, London, pp: 107-107.

Stewart, G.R. and M.C. Press, 1990. The physiology and biochemistry of parasitic angiosperms. Ann. Rev. Plant Physiology Plant Molecular Biology, 41: 127-151. DOI: 10.1146/annurev.pp.41.060190.001015 